\title{
First Record of Hemiberlesia musae Takagi \& Yamamoto, 1974 and Duplachionaspis divergens (Green, 1899) (Hemiptera: Diaspididae) on Sugarcane in Greenhouse in Brazil
}

\author{
Gabriel G. Monteiro ${ }^{1}$, Vera R. dos S. Wolff ${ }^{2}$, Ana Lúcia B. G. Peronti ${ }^{1}$, Nilza M. Martinelli ${ }^{1} \&$ Ivan A. dos Anjos ${ }^{3}$ \\ 1 Faculdade de Ciências Agrárias e Veterinárias, Universidade Estadual Paulista "Júlio de Mesquita Filho", \\ Jaboticabal, SP, Brazil \\ ${ }^{2}$ Centro de Pesquisa em Produção Vegetal, Departamento de Diagnóstico e Pesquisa Agropecuária, Secretaria de \\ Agricultura, Pecuária e Irrigação de Porto Alegre, RS, Brazil \\ ${ }^{3}$ Instituto Agronômico de Campinas, Ribeirão Preto, SP, Brazil \\ Correspondence: Gabriel G. Monteiro, Departamento de Fitossanidade, Faculdade de Ciências Agrárias e \\ Veterinárias, Universidade Estadual Paulista "Júlio de Mesquita Filho", Via de acesso Prof. Paulo Donato \\ Castellane, s/n, 14884-900, Jaboticabal, São Paulo, Brazil. Tel: 55-163-209-7311. E-mail: \\ gabrielmonteiro7777@hotmail.com
}

Received: October 17, 2018

doi:10.5539/jas.v11n2p392
Accepted: November 25, $2018 \quad$ Online Published: January 15, 2019

URL: https://doi.org/10.5539/jas.v11n2p392

\begin{abstract}
The armored scales Hemiberlesia musae Takagi and Yamamoto, 1974 and Duplachionaspis divergens (Green, 1899) (Hemiptera: Diaspididae) were collected on the base of the stem and on leaves of sugarcane plants, Saccharum spp. (Poales: Poaceae), cultivated in plastic pots in greenhouses in the municipalities of Jaboticabal and Ribeirão Preto, São Paulo, respectively. This is the first report of $D$. divergens in Brazil and $H$. musae on Saccharum host plants.
\end{abstract}

Keyswords: insect-plant interaction, invasive species, Saccharum spp.

\section{Introduction}

Sugarcane Saccharum spp. (Poales: Poaceae) was introduced in Brazil in 1502 from seedlings of the Madeira Island (Landell \& Almeida Silva, 2004). At present, the country is the largest producer of sugarcane, being one of its main "commodities" (Lucchesi, 1995; Arruda Pinto, 2002).

In order to increase the productivity of sugarcane, several genetically improved varieties were introduced (Embrapa, 2018). However, phytosanitary problems persist, especially those caused by viruses, bacteria, fungi and arthropods (Bianchini et al., 2005).

Among the significant insect-pests that attack sugarcane in the country are: Lepidoptera species of the genus Diatraea, Elasmopalpus, Hyponeuma and Telchin, leafhoppers of the genus Mahanarva, Coleoptera of the genus Metamasius, Migdolus and Sphenophorus and termites (Costa Lima, 1968). Among the coccoids, 16 species from 5 families were recorded in Brazil (Table 1). Saccharicoccus sacchari (Cockerell, 1895) and Aclerda takahashii (Kuwana, 1932) have been frequent in crop areas (Gallo et al., 2002). 
Table 1. Scale insects recorded on sugarcane plants in Brazil

\begin{tabular}{|c|c|c|}
\hline Scale insects & Distribution in Brazil & References \\
\hline \multicolumn{3}{|l|}{ Aclerdidae } \\
\hline Aclerda takahashii (Kuwana. 1932) & SP, RS & (Oliz \& Wolff, 2014; García Morales et al., 2016) \\
\hline \multicolumn{3}{|l|}{ Coccidae } \\
\hline Saissetia oleae (Olivier, 1791) & & (Costa Lima, 1968) \\
\hline \multicolumn{3}{|l|}{ Diaspididae } \\
\hline Melanaspis saccharicola (Lima, 1934) & RJ & (Claps et al., 1999) \\
\hline Melanaspis smilacis (Comstock, 1883) & RJ, SP & (Costa Lima, 1968; Claps et al., 2001) \\
\hline Mycetaspis apicata Newstead, 1920 & RJ & (Costa Lima, 1968; Claps et al., 2001) \\
\hline Diaspis bromeliae (Kerner, 1778) & RJ, SP & (Costa Lima, 1968) \\
\hline Odonaspis saccharicaulis (Zehntner, 1897) & RJ, SP & (Costa Lima, 1968; Claps et al., 1999; Claps et al., 2001) \\
\hline *Hemiberlesia musae Takagi \& Yamamoto, 1974 & SP & \\
\hline *Duplachionaspis divergens (Green, 1899) & SP & \\
\hline \multicolumn{3}{|l|}{ Margarodidae } \\
\hline Eurhizococcus brasiliensis (Wille, 1922) & & (Costa Lima, 1968) \\
\hline Margarodes sp. & RS & (Costa Lima, 1968) \\
\hline Margarodes carvalhoi Costa Lima, 1950 & PE & (Costa Lima, 1968) \\
\hline \multicolumn{3}{|l|}{ Pseudococcidae } \\
\hline Dysmicoccus boninsis Kuwana, 1909 & MG, RJ, SP & (Costa Lima, 1968) \\
\hline Dysmicoccus brevipes (Cockerell, 1893) & & (Costa Lima, 1968) \\
\hline Planococcus citri (Risso, 1813) & & (Costa Lima, 1968) \\
\hline Pseudococcus sp. & & (Costa Lima, 1968) \\
\hline Saccharicoccus sacchari (Cockerell, 1895) & MG, MT, RJ, SP, SC & (Costa Lima, 1968) \\
\hline Trionymus sp. & & (Costa Lima, 1968) \\
\hline
\end{tabular}

Note. *Species found in the state of São Paulo in the present work.

This work aimed to register Hemiberlesia musae Takagi \& Yamamoto, 1974 and Duplachionaspis divergens (Green, 1899) (Hemiptera: Diaspididae) on plants of Saccharum spp. (Poales: Poaceae) in greenhouses in two municipalities in the State of São Paulo.

\section{Material and Methods}

\subsection{Presence of the Armored Scales on Sugarcane}

Two species of armored scales were observed infesting sugarcane plants in greenhouse in the State of São Paulo, Brazil, in March 2018: (sp1.) collected by the first author (GGM) on the basal part of the stem (Figure 1) in about $10 \%$ of the 320 plants cultivated, at the Experimental Farm of the Faculty of Agrarian and Veterinary Science (FCAV), Paulista State University "Júlio de Mesquita Filho" (UNESP), Jaboticabal-SP; and (sp2.) collected by the fifth author (IAA), on the leaves, along the ribs, mainly on the adaxial region (Figure 1), at the Canavieira Techonology Center (CTC) and Interuniversity Network for the Development of the Sugarcane Sector (RIDESA), in Ribeirão Preto-SP. 

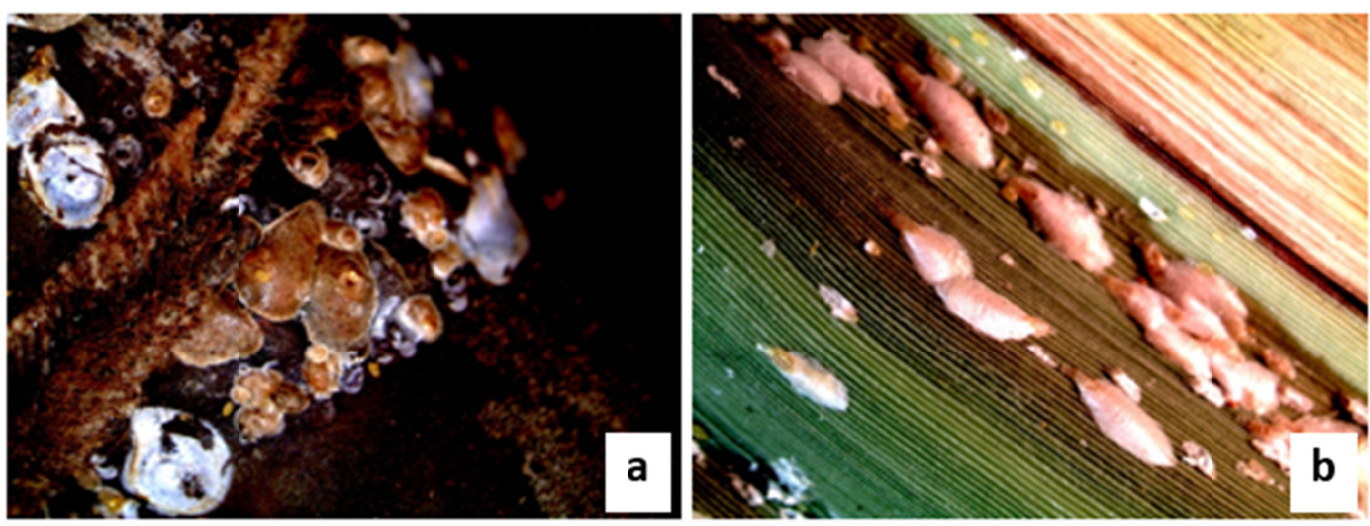

Figure 1. Macroscopic aspects of armored scales found on sugarcane in greenhouses in the state of São Paulo: (a) Hemiberlesia musae, (b) Duplachionaspis divergens

\subsection{Slide-Mounted Procediments for the Armored Scales}

The specimens were fixed in 70\% alcohol and transported to the Laboratory of Entomology in the Department of Phytossanitary of Agrarian and Veterinary Sciences (FCAV), Paulista State University (UNESP). The insects were mounted on permanent slides using the techinique described by Granara de Wilink (1990).

Initially, the diaspidids were separeted into genus by the third author (ALBGP) and later duplicates were sent to the second author (VRSW) who identified them at the species level. The armored scales were slide-mounted following the adapted techniques by Wolff (2001) and were identified according to the morphological characteristics of the female adult as described by Normark et al. (2014), Caballero et al. (2017), Yu and Suh (2012), Chen (1983), Chou (1982), Kuwana (1928), and MacGillivray (1921).

\subsection{Storage of Voucher Species}

The vouchers species were deposited in the Reference Collection of Insects and Mites (CRIA) of the Department of Phytosanitary of FCAV/UNESP, Jaboticabal, SP; and in the Center for Research in Plant Production, Department of Diagnosis and Agricultural Research, Secretariat of Agriculture, Livestock and Irrigation in Porto Alegre, Rio Grande do Sul.

\section{Results and Discussion}

\subsection{Identification}

All the collected specimens on sugarcane in the greenhouse in Jaboticabal were identified as H. musae and those collected in Ribeirão Preto identified as $D$. divergens.

\subsection{Hemiberlesia musae}

Hemiberlesia musae is a species of Neotropical origin with probable center of origin in the North Region from the South America, described from specimens collected on banana plants, Musa spp. (Zingiberales: Musacea), in Ecuador. Later it was also registered in Puerto Rico on the same host plant (Takagi \& Yamamoto, 1974) and in Brazil on plants of Persea americana (Laurales: Lauraceae) (Normark et al., 2014).

The adult female presents elongated and membranous body, except for the slightly sclerotized and acute pygidium (Figure 2). Well-developed median lobes, as long as broad, parallel, with a notch on both sides, separated from each other by a pair of fringed plates. Second pair of lobes much smaller, longer than wide, with a notch on the outer side, separated from the medial lobes by a pair of fringed plates longer than the second lobes. Third pair of lobes reduced in lenght, narrow, strongly sclerotizated, with a notch on the outer side and pointed apex, separated from the second lobes by a pair of fringed plates. Laterally to the third pair of lobes, three thin and simple plates, with the base broad and serrated. Large, elliptical anal opening, compared to the medial lobes is at a distance about 1.5 times the length of these. Perivulvar pores absent, long dorsal macroducts, nine or ten on each side of the pygidium, absent between the medial lobes. Very small or obsolete paraphyses. Prepygidium macroducts much smaller from pygidium (Takagi \& Yamamoto, 1974). 

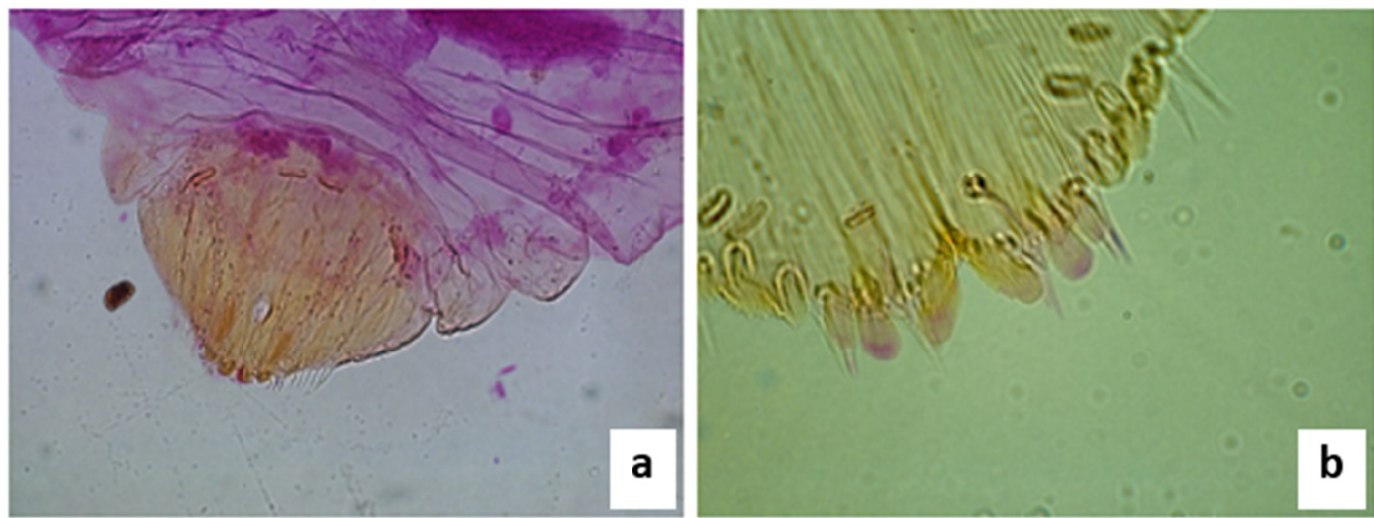

Figure 2. Microscopic aspects of the pygidium: (a) Hemiberlesia musae, (b) Duplachionaspis divergens

\subsection{Duplachionaspis divergens}

Duplachionaspis divergens, probably originated from the Eastern or Paleartic Region was described from samples collected in Sri Lanka on plants of Cymbopogon nardus (= Andropogon nardus) (Poales: Poaceae) (Green, 1899; Hall et al., 2005). This is monophagous registered on 23 host plants species of the Poaceae, distributed in 18 genera. In India is considered as a minor pest on sugarcane, however the adult females lay around 130 eggs, and the species produce nine generations per year (Evans \& Hodges, 2007; Lastra \& Gomes, 1997). Currently, occur in all zoogeographical regions: Neartic (United States of America), Paleartic (Algeria, Japan and South Korea), Neotropical (Antigua and Barbuda, Colombia and Venezuela), Ethiopia (Egypt), Oriental (India, China, Cambodia, Sri Lanka, Taiwan, Thailand and Vietnam) and Australian (Australia) (García Morales, 2016). In the State of Florida, it was observed on sugarcane plants cultivated in greenhouse (Hall et al., 2005; Evans \& Hodges, 2007).

The adult female presents the elongated body, with 4-5 lateral lobes. In the pygidium, well-developed and divergent medial lobes, not baseline joined, without glandular spines between them; second pair of bilobed lobes, rounded with a pair of glandular spines between these and the median lobes (Figure 2); third pair of lobes inconspicuous, after five glandular spines at the margin on each side; one marginal macroduct opens between the median lobes and the second pair of lobes, two between the second pair and the third pair of lobes and four marginal macroducts after the latter. Perivulvar pores in five groups, anus in the center of the pygidium (Green, 1899; Yu \& Suh, 2012).

\section{Conclusion}

Associated with the sugarcane plants in Brasill are now known 18 species of scale insects, seven from the family Diaspididae, Hemiberlesia musae and D. divergens are the first to be registered in greenhouses in the country.

\section{Acknowledgements}

We thank to the Coordination of Improvement of Higher Education Personnel (CAPES) for the grants.

\section{References}

Arruda Pinto, R. S. D. (2002). Indicadores de desempenho de frota de empresas agroindustriais canavieiras brasileiras (Master's thesis, Escola Superior de Agricultura "Luiz de Queiroz", Universidade de São Paulo).

Bianchini, A., Maringoni, A. C., \& Carneiro, S. M. T. P. G. (2005). Manual de fitopatologia: doenças das plantas cultivadas. Agronômica Ceres, 2, 333-349.

Caballero, A., Ramos Portilla, A. A., \& Kondo, T. (2017). Scale insects (Hemiptera: Coccomorpha) on sugarcane in Colombia, with description of a new species of Tillancoccus Ben-Dov (Coccidae). Zootaxa, 4258(5), 490-500. https://doi.org/10.11646/zootaxa.4258.5.6

Chen, F. G. (1983). The Chionaspidini (Diaspididae, Coccoidea, Homoptera) from China. Science \& Technology Publishing House, 175.

Chou, I. (1982). Monograph of the Diaspididae of China. House of Science \& Technology, 1.

Claps, L. E., Wolff, V. R. S., \& Gonzáles, R. H. (1999). Catálogo de las especies de Diaspididae (Hemiptera: Coccoidea) nativas de Argentina, Brasil y Chile. Insecta Mundi, 13, 239-256. 
Claps, L. E., Wolff, V. R., \& González, R. H. (2001). Catálogo de las Diaspididae (Hemiptera: Coccoidea) exóticas de la Argentina, Brasil y Chile. Revista de la Sociedad Entomológica Argentina, 60, 9-34.

Costa Lima, A. M. (1968). Quarto catálogo dos insetos que vivem nas plantas do Brasil seus parasitos e predadores. Parte II-1 Tomo Insetos, Hospedeiros e Inimigos Naturais. Catálogos dos Insetos que Vivem nas Plantas do Brasil. Rio de Janeiro, GB, Brazil.

Embrapa. (2018). In Agência Embrapa de Informação e Tecnologia. Retrieved June 8, 2018, from http://www.embrapa.br

Evans, G. A., \& Hodges, G. S. (2007). Duplachionaspis divergens (Hemiptera: Diaspididae), a new exotic pest of sugarcane and other grasses in Florida. Florida Entomologist, 90, 392-393. https://doi.org/10.1653/ 0015-4040(2007)90[392:DDHDAN]2.0.CO;2

Gallo, D., Nakano, O., Wiendl, F. M., Silveria Neto, S., \& Carvalho, R. P. L. (1970). Manual de entomologia. Editora Agronômica Ceres, São Paulo.

García Morales, M., Denno, B. D., Miller, D. R., Miller, G. L., Bem-Dov, Y., \& Hardy, N. B. (2016). ScaleNet: A literature-based modelo $f$ scale insect biology and systematics. Retrieved June 9, 2018, from http://scalenet.info

Granara de Willink, M. C. (1990). Conociendo nuestra fauna I: superfamilia Coccoidea (Homoptera: Sternorrhyncha) (Doctoral dissertation, Facultad de Ciencias Naturales e Instituto Miguel Lillo, Universidade Nacional de Tucumán, Argentina).

Green, E. E. (1899). The Coccidae of Ceylon, Part II (pp. 105-169). Dulau.

Hall, D. G., Konstantinov, A. S., Hodges, G. S., Sosa, O., Welbourn, C., \& Westcott, R. L. (2005). Insects and Mites New to Florida Sugarcane. Journal American Society Sugar Cane Technologists, 25, 143-156.

Kuwana, S. I. (1928). The diaspine Coccidae of Japan, V. Genera Chionaspis, Tsukushiaspis [n. gen.], Leucaspis, Nikkoaspis [n. gen.]. Scientific Bulletin, 1, 1-39.

Landell, M. G. A., \& Almeida Silva, M. (2004). As estratégias de seleção da cana em desenvolvimento no Brasil. Visão Agrícola, 1, 18-23.

Lastra, L. A., \& Gomez, L. A. (1997). Observaciones del ciclo de vida de la escama blanca, Duplachionaspis divergens (Green) (Homoptera: Diaspididae) y reconcimiento de enemigos naturals (pp. 24-26). IV Congresso Colombiana de la Asociación de Técnicos de la Cana de Azucar, Cali, Colombia.

Lucchesi, A. A. (1995). Processos fisiológicos da cultura da cana-de-açúcar (Saccharum spp.). Piracicaba: ESALQ/USP.

MacGillivray, A. D. (1921). The Coccidae. Tables for the Identification of the Subfamilies and Some of the More Important Genera and Species, together with Discussions. Scarab Urbana, 3, 502. https://doi.org/10.5962/ bhl.title.21115

Normark, B. B., Morse, G. E., Krewinski, A., \& Okusu, A. (2014). Armored Scale Insects (Hemiptera: Diaspididae) of San Lorenzo National Park, Panama, with Descriptions of Two New Species. Annals of the Entomological Society of America, 107, 37-49. https://doi.org/10.1603/AN13110

Oliz, C. B., \& Wolff, V. R. S. (2014). Primeiro registro de Aclerda takahashii (Coccoidea: Aclerdidae) no Rio Grande do Sul, Brasil. Pesquisa Agropecuária Gaúcha, 20, 162-167.

Takagi, S., \& Yamamoto, M. (1974). Two new banana-infesting scale insects of Hemiberlesia or Abgrallaspis from Ecuador (Homoptera: Coccoidea). Insecta Matsumurana, 3, 35-42.

Yu, H. M., \& Suh, S. J. (2012). A new record for the genus Duplachionaspis armored scale (Hemiptera: Diaspididae) from Korea. Korean Journal of Applied Entomology, 52, 63-67. https://doi.org/10.5656/KSAE. 2013.01.0.001

\section{Copyrights}

Copyright for this article is retained by the author(s), with first publication rights granted to the journal.

This is an open-access article distributed under the terms and conditions of the Creative Commons Attribution license (http://creativecommons.org/licenses/by/4.0/). 